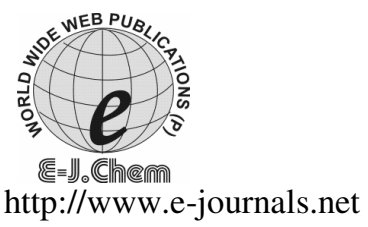

\title{
Simple Sensitive Spectrophotometric Determination of Vanadium in Biological and Environmental Samples
}

\author{
B. KRISHNA PRIYA, P. SUBRAHMANYAM, \\ J. DILIP KUMAR and P. CHIRANJEEVI* \\ *Environmental Monitoring Laboratory \\ Department of Chemistry \\ S.V.University, Tirupati-517502, A.P.,INDIA
}

Received 13 July 2006; Accepted 22 August 2006

\begin{abstract}
Novel, rapid, highly sensitive and selective spectrophotometric method for the determination of traces of vanadium (V) in environmental and biological samples, pharmaceutical and steel samples was studied. The method is based on oxidation of 2,4- dinitro phenyl hydrazine(2,4-DNPH) by vanadium (V) followed by coupling reaction with $N$-(1-naphthalene-1-yl)ethane-1,2-diaminedihydrochloride (NEDA) in acidic medium to give red colored derivative or on oxidation of 4-Amino Pyridine by vanadium (V) followed by coupling reaction with NEDA in basic medium to give pink colored derivative. The red colored derivative having an $\lambda_{\max } 495 \mathrm{~nm}$ which is stable for 8 days and the pink colored derivative with $525 \mathrm{~nm}$ is stable for more than 7 days at $35{ }^{\circ} \mathrm{C}$. Beer's law is obeyed for vanadium (V) in the concentration range of $0.02-3.5 \mu \mathrm{g} \mathrm{ml}{ }^{-1}$ (red derivative) and $0.03-4.5 \mu \mathrm{g} \mathrm{ml}^{-1}$ (pink derivative) at the wave length of maximum absorption. The optimum reaction conditions and other analytical parameters were investigated to enhance the sensitivity of the present method. The detailed study of various interferences made the method more selective. The proposed method was successfully applied to the analysis of vanadium in natural water samples, plant material, soil samples, synthetic mixtures, pharmaceutical samples and biological samples. The results obtained were agreed with the reported methods at the $95 \%$ confidence level. The performance of proposed method was evaluated in terms of Student's $t$-test and Variance ratio $f$-test which indicates the significance of proposed method over reported method.
\end{abstract}

Keywords: Oxidation, $N$-(1-naphthalene-1-yl)ethane1,2diaminedihydrochloride (NEDA), Spectrophotometry, Environmental, Biological, Pharmaceutical and steel samples. 


\section{Introduction}

Vanadium and its compounds used extensively in the steal and petrochemicals industries. Vanadium species are most stable and more toxic. Vanadium affects the numerous physiological processes and biochemical reactions. Vanadium remains a relatively unknown trace element, as its uses are still being targeted in various clinical applications worldwide. However, vanadium deficiency consistently impairs biological function is lacking. Vanadium content in food is directly dependant upon the concentrations present in the soil. Once consumed, vanadium is stored primarily in fatty tissues, with the remaining amounts stored in the kidney, liver, spleen, or bone. Vanadium is a trace element of highly critical role in biochemical processes and of significant importance in environmental, biological and industrial analysis due to its toxicity. Vanadium in trace amounts is an essential element for cell growth at $\mu \mathrm{g} \mathrm{l}^{-1}$ levels, also has been shown to inhibit cholesterol synthesis and to increase the oxidation of fatty acids of higher concentrations. It is excreted through urine. The amount of vanadium in blood and urine depends upon intensity and duration of its exposure. Vanadium also regarded as beneficial element that helps in the carbohydrates metabolism, prevention of some heart diseases, and also essential for certain animals plants and microorganism.

Vanadium acts as a growth-promoting factor and participates in fixation and accumulation of nitrogen in plants, whereas high concentration of vanadium reduces the productivity of the plants ${ }^{1}$. Therefore, the determination of vanadium in environmental and biological samples is highly desirable. In survey of literature reveals that several analytical techniques have been reported for the determination of vanadium such as high performance liquid chromatography ${ }^{2}$, voltammetry ${ }^{3}$, atomic absorption spectrometry ${ }^{4,5}$, spectrofluorimetry ${ }^{6}$, atomic emission spectrometry ${ }^{7}$ and ion chromatography inductively coupled plasma optical emission spectrometry ${ }^{8}$, have also some limitations in terms of high cost of instruments used in routine analysis and matrix effects. These techniques suffer from several disadvantages such as few techniques are expensive (AAS, ICP-AES and IC-ICP-OES), few other have poor sensitivity and few others are require specific electrodes for the determination of vanadium.

In scrutiny of literature reveals that several spectrophotometric methods have been reported for the determination of vanadium in environmental and biological samples. Recently, few authors introduced various reagents for spectrophotometric determination of vanadium in various samples such as 2-(2-quinolylazo)-5-diethylaminophenol ${ }^{9}$, variamineblue $^{10}$, cryamine $^{11}$, Benzylacetate ${ }^{12}$, pyrogallol $^{13}, \quad$ 2-(8-quinolylazo)-5dimethylaminopheno $^{14}$, 2-hydroxyacetophenone ${ }^{15}$, 4-(2-pyridylazo) resorcinol ${ }^{16}$, tannic $\operatorname{acid}^{17}$, 2-(5-chloro-2-pyridylazo)-5-dimethylaminophenol 18 and $N, N^{\prime}$-bis(2-hydroxyl-3sulfopropyl)-tolidine ${ }^{19}$. The above reported reagents are suffers from poor selectivity, interference of large number of metal ions, require specific solvent for the extraction of color species and few other are require activators for catalytic photometric determination of vanadium. These deficiencies have encouraged the authors to develop novel reactions for facile, sensitive, accurate and reliable method for the determination of trace amounts of vanadium in environmental and biological samples. These types of reactions for the determination of vanadium $(\mathrm{V})$ have not been reported yet.

In this paper, we develop novel reactions for rapid, facile, sensitive, and selective spectrophotometric methods for the determination of traces of vanadium (V). The implied reactions are oxidative coupling in the presence of $\mathrm{V}^{5+}$ of 2, 4-dinitrophenylhydrazine with 
$N$-(1-naphthyl) ethylenediamine dihydrochloride (NEDA) and 4-amino pyridine with NEDA, yielding the highly stable red and pink color derivatives and it was shown in Scheme 1. Based on this highly sensitive, selective and rapid methods were applied for the determination of vanadium (V) in environmental, biological and steel samples.

\section{Experimental}

\section{Instrumentation}

A HITACHI U 2001 spectrophotometer with $1 \mathrm{~cm}$ matched quartz cells were used for all absorbance measurements. A pH meter, Elico Li-129 Model glass-electrode was employed for measuring $p \mathrm{H}$ values.

\section{Reagents and solutions}

All chemicals and solvents used were of analytical reagent grade, and doubly distilled water was used to prepare all solutions in the experiments. Standard stock solution containing $100 \mathrm{mg} \mathrm{l}^{-1}$ of vanadium (V) was prepared by dissolving $0.2393 \mathrm{~g}$ of ammonium vanadate (E-Merck, India) in $1000 \mathrm{ml}$ volumetric flask and diluted up to the mark with $0.01 \mathrm{M} \mathrm{HCl}$. Working solutions were prepared by appropriate dilution of the standard solution.

An aqueous solution of 1.5\% $(w / v)$ NEDA/2,4-dinitro phenyl hydrazine1:2 reagent solution was prepared by dissolving $1 \mathrm{~g}$ of NEDA (from Sigma, USA), $0.5 \mathrm{~g}$ of 2,4- DNPH (from SD Fine Chemicals, India), and a few drops of concentrated $\mathrm{HCl}$, diluted up to the mark with doubly distilled water and the solutions were refrigerated. $0.5 \%(w / v) 4$ - amino pyridine reagent solution was prepared by dissolving $0.5 \mathrm{~g}$ of 4- amino pyridine (from SD Fine Chemicals, India) in $100 \mathrm{ml}$ of Aqueous methanol was used for the experiments.

Phosphate buffer solution was prepared by dissolving $13.6 \mathrm{~g}$ of Potassium dihydrogen phosphate in $80 \mathrm{ml}$ of water and adjusting the $p \mathrm{H}$ to 3.0 with hydrochloric acid, and the mixture was diluted to $100 \mathrm{ml}$ with doubly distilled water.

Phosphate buffer $p \mathrm{H} 8$ was prepared by dissolving $50 \mathrm{ml}$ of $0.2 \mathrm{M}$ Potassium dihydrogen phosphate in $46.8 \mathrm{ml}$ of $0.2 \mathrm{M} \mathrm{NaOH}$ and adjusting the $p \mathrm{H}$ to 8 , and the mixture was diluted to $500 \mathrm{ml}$.

\section{General procedure}

\section{2,4-DNPH - NEDA method}

Stock solutions containing $\left(0.02-3.5 \mu \mathrm{g} \mathrm{ml}^{-1}\right)$ of vanadium $(\mathrm{V})$ (the volume of the test solution was restricted to $1 \mathrm{ml}$ ) were transferred into $25 \mathrm{ml}$ calibrated flasks; $2 \mathrm{ml}$ of $1.5 \%$ 2,4-DNPH - NEDA reagent solution and $3 \mathrm{ml}$ of phosphate buffer were added to each flask, the red color is formed instantaneously and diluted up to the mark. After dilution of $25 \mathrm{ml}$ with water, the absorbance at $495 \mathrm{~nm}$ was measured against the corresponding reagent blank and the calibration graph was constructed.

\section{4-Amino Pyridine-NEDA method}

An aliquot of sample solutions containing $\left(0.03-4.5 \mu \mathrm{g} \mathrm{ml}^{-1}\right)$ of vanadium $(\mathrm{V})$ were transferred to $25 \mathrm{ml}$ standard flask; to each flask, $2 \mathrm{ml}$ of 1.5\% 4-Amino Pyridine - NEDA reagent solution and $3 \mathrm{ml}$ of phosphate buffer were added. Each mixture was allowed to stand for $2 \mathrm{~min}$ with occasional shaking to complete the reaction. After dilution to $25 \mathrm{ml}$ with water, the absorbance at $525 \mathrm{~nm}$ was measured against the corresponding reagent blank and the calibration graph was constructed. 


\section{Procedure for Determination of Vanadium in soil sample}

An air-dried homogenized soil sample $(1 \mathrm{~g})$ was weighed accurately and placed in a 100-ml Kjeldahl flask. The sample was digested in the presence of an oxidizing agent following the method recommended by ${ }^{15}$. The content of flask was filtered through a Whatman No. 40 filter paper, into a $25 \mathrm{ml}$ calibrated flask and neutralized with dilute ammonia in the presence of $1-2 \mathrm{ml}$ of $0.01 \%(\mathrm{w} / \mathrm{v})$ tartrate solution. It was then diluted to the mark with water. Appropriate aliquots of 1-2 $\mathrm{ml}$ of the solution was transferred into a 25 -ml calibrated flask and analyzed for vanadium content according to the general procedure, after adding 1$2 \mathrm{ml}$ of $0.01 \%(\mathrm{w} / \mathrm{v})$ thiocyanate or fluoride solution as masking agent.

\section{Procedure for Determination of Vanadium in water sample}

Each filtered environmental water sample $(100 \mathrm{ml})$ was analyzed for vanadium. They tested negative. To these samples known amounts of vanadium $(\mathrm{V})$ were added and analyzed by the proposed procedure for vanadium.

\section{Procedure for Determination of Vanadium in urine sample}

$50 \mathrm{ml}$ of the urine sample was concentrated to $5 \mathrm{ml}$, by evaporation. To this solution was spiked a known amount of vanadium and mixed with $5 \mathrm{ml}$ of concentrated $\mathrm{HNO}_{3}$ and $5 \mathrm{~g}$ of potassium sulfate, and heated to dryness. The process was repeated 2-3 times. Then HNO3 $(1: 3,25 \mathrm{ml})$ was added to the residue and digested on a water bath for $30 \mathrm{~min}$. The contents were again evaporated to dryness, cooled, and the residue was dissolved in water, filtered, and neutralized with dilute ammonia. The mixture was diluted to a known volume with water. Appropriate aliquots of this solution were taken and the proposed general procedure was followed for the vanadium determination.

\section{Procedure for Determination of Vanadium in biological samples}

The samples of plants and animal tissues were washed with distilled water to get them free from adhering soil or blood. They were carefully wiped with filter paper before taking their wet weight. The samples were then dried, ashed and brought into solution by acid treatment as per standard procedures ${ }^{20}$ and neutralized with dilute $\mathrm{NH}_{4} \mathrm{OH}$ and then diluted to a known volume with water. An appropriate aliquot of this solution was finally analyzed according to the general procedure for vanadium. Since the vanadium content in samples used was negligible, synthetic samples were prepared by the addition of known amounts of vanadium to each sample prior to digestion.

\section{Procedure for Determination of vanadium in pharmaceutical samples}

A volume of $15 \mathrm{ml}$ of elixir sample was treated with $10 \mathrm{ml}$ of concentrated $\mathrm{HNO}_{3}$; the mixture was then evaporated to dryness. The residue was leached with $5 \mathrm{ml}$ of $0.5 \mathrm{M} \mathrm{H}_{2} \mathrm{SO}_{4}$. The solution was diluted to a known volume with water, after neutralizing with dilute ammonia. An aliquot of the made up solution was analyzed for vanadium according to the general procedure for vanadium determination.

\section{Procedure for Determination of Vanadium in alloy steels}

A $0.1 \mathrm{~g}$ amount of a steel sample containing $0.13 \%$ of vanadium was weighed accurately and placed in a $50-\mathrm{ml}$ beaker. To it, was added $10 \mathrm{ml}$ of $20 \%(\mathrm{v} / \mathrm{v}) \mathrm{H}_{2} \mathrm{SO}_{4}$ and carefully covered with a watch glass until the brisk reaction subsided. The solution was heated and simmered gently after addition of $5 \mathrm{ml}$ of concentrated $\mathrm{HNO}_{3}$ until all carbides were decomposed. Then, $2 \mathrm{ml}$ of a 1:1 (v/v) $\mathrm{H}_{2} \mathrm{SO}_{4}$ solution was added and the mixture was 
evaporated carefully until the dense white fumes drived off the oxides of nitrogen, and then cooled to room temperature. After appropriate dilution with water, the contents of the beaker were warmed to dissolve the soluble salts. The solution was then cooled and neutralized with a dilute $\mathrm{NH}_{4} \mathrm{OH}$ solution in the presence of $1-2 \mathrm{ml}$ of $0.01 \%(\mathrm{w} / \mathrm{v})$ tartrate. The resulting solution was filtered, if necessary, through a Whatman No. 40 filter paper into a calibrated flask of known volume. The residue (silica) was washed with a small volume of hot $1 \% \mathrm{H}_{2} \mathrm{SO}_{4}$ followed by water and the volume was made up to the mark with water.

A suitable aliquot of the above solution was taken into a $25-\mathrm{ml}$ calibrated flask and the vanadium content was determined by the general procedure using 1-2 $\mathrm{ml}$ of saturated thiocyanate or fluoride solution as masking agent. Iron (III) can be effectively removed from the solution by precipitation with saturated fluoride solution. The precipitates were filtered off before the addition of 2,4- DNPH- NEDA and 4-amino pyridine - NEDA. Higher concentrations of iron (III) were removed by adding 5-10 ml of saturated ammonium thiocyanate solution to the test solution, and the resulting Fe (III) and Fe (II) complexes with thiocyanate were extracted into methyl isobutyl ketone (MIBK) in an aqueous acidic medium prior to the determination of vanadium.

\section{Results and Discussion}

\section{Absorption spectra of color derivatives}

The proposed methods involved the formation red color derivative with a $\lambda_{\max }$ of $495 \mathrm{~nm}$ or pink color derivative with $\lambda_{\max } 525 \mathrm{~nm}$ and the measurement of their absorption spectra was shown in Figure 1. The reagent blanks had negligible absorption at these wavelengths.

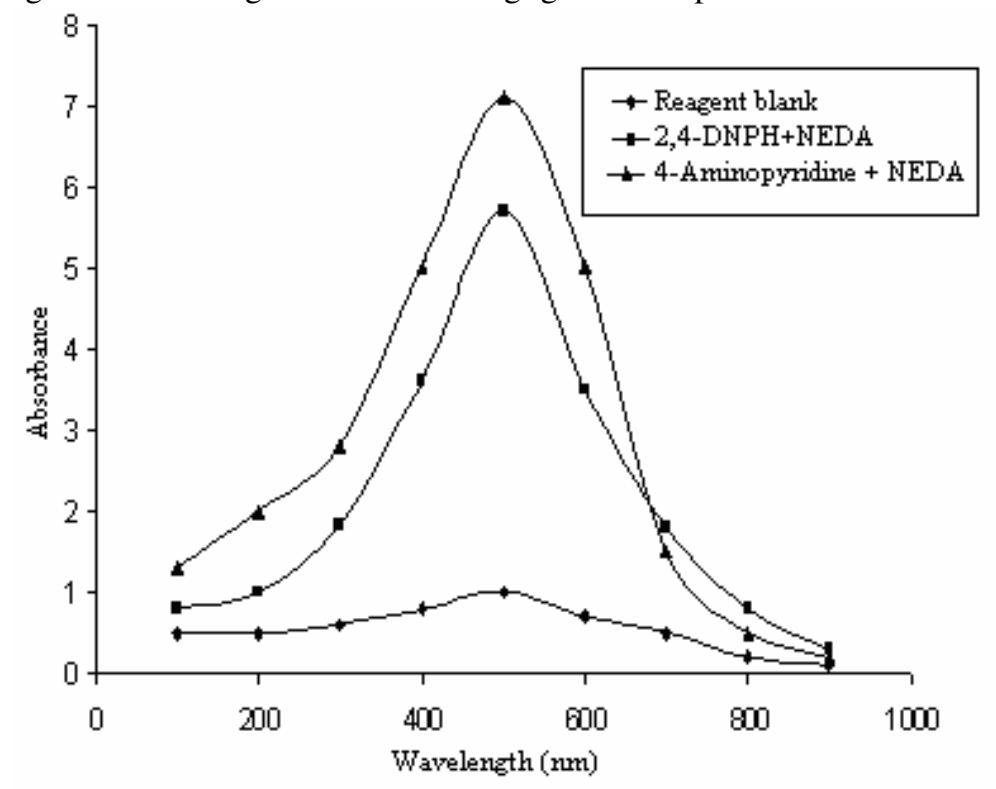

Figure 1. Absorption spectra of oxidative coupling reaction of 2,4 DNPH+NEDA and 4Aminopyridine +NEDA with vanadium (V)

Under the optimized conditions, although the color developed instantaneously, one min was allowed to obtain the maximum and constant absorbance in both colored derivatives. The red color derivative was stable for 15 days and the pink color derivative for 9 days. 
The absorbance varied by $\pm 2 \%$ within two days for both red and pink color derivatives. The color development was independent of temperature in the range of $20-35{ }^{\circ} \mathrm{C}$.

\section{Effect of reagent and acid concentration}

The effect of 2,4-DNPH -NEDA mixture was studied in the range of $1-8 \mathrm{ml}$ of a $1.5-\%$ $(w / v)$ solution of 2,4-DNPH -NEDA in water. To achieve the maximum color intensity, a volume of $2-4 \mathrm{ml}$ of this solution was necessary. Hence, $3 \mathrm{ml}$ of 1.5\% 2,4-DNPH -NEDA in water were selected for further studies, under optimized conditions. The maximum intensity of the red color was achieved in basic medium of $p \mathrm{H} 8$.

The maximum intensity of the pink color was achieved in the range of $3-5 \mathrm{ml}$ of concentrated sulfuric acid for 4-amino pyridine - NEDA reagent mixture. Therefore, $4 \mathrm{ml}$ of concentrated sulfuric acid was used for best results. A range of $2-4 \mathrm{ml}$ of a $1.5 \%(\mathrm{w} / \mathrm{v})$ solution of 4-amino pyridine - NEDA in water and $3-5 \mathrm{ml}$ of $0.5 \%(w / v)$ solution of NEDA in water were necessary to achieve the maximum color intensity. Hence, $2 \mathrm{ml}$ of $0.5 \%$ 4-amino pyridine and $4 \mathrm{ml}$ of $0.5 \%$ NEDA were employed for the experiments under optimized conditions.

\section{Analytical data}

Linear calibration graphs were obtained for $0.02-8.0 \mu \mathrm{g} \mathrm{ml}^{-1}$ for 2,4-DNPH-NEDA and 0.03 $8.0 \mu \mathrm{g} \mathrm{ml}^{-1}$ for 4-amino pyridine of vanadium in a final volume of $25 \mathrm{ml}$. The detection limit and limit of quantification of vanadium determination were found to be 0.358 and $2.893 \mu \mathrm{g} \mathrm{ml}^{-1}$ for 2, 4-DNPH-NEDA and 0.704 and $3.362 \mu \mathrm{g} \mathrm{ml}^{-1}$ for 4-AP-NEDA respectively. The calibration graph has correlation coefficient of 0.9987 for 2,4-DNPH-NEDA and 0.9998 for 4AP-NEDA methods. Beer's law range, molar absorptivity, Sandell's sensitivity, and other parameters of the oxidative-coupling mixtures are given in Table 1. The precision and accuracy of the method was studied by analyzing the coupling solution containing known amounts of the cited reagents within Beer's law limit. The low values of the relative standard deviation in (in \%) and the percentages of error indicated the high accuracy of the two experiments.

Table 1. Optical characteristics, precision and accuracy of the spectrophotometric determination of vanadium with 2,4- DNPH-NEDA and 4-Amino Pyridine - NEDA

\begin{tabular}{|c|c|c|}
\hline Optical characteristics & $\begin{array}{l}\text { 2,4-DNPH- } \\
\text { NEDA method }\end{array}$ & 4-AP-NEDA method \\
\hline Concentration range $\left(\mu \mathrm{g} \mathrm{ml}^{-1}\right)$ & $0.02-3.5$ & $0.03-4.5$ \\
\hline Color & red & pink \\
\hline$\lambda_{\max }(\mathrm{nm})$ & 495 & 525 \\
\hline Stability & 8days & More than 7 days \\
\hline Molar absorptivity $\left(1 \mathrm{~mol}^{-1} \mathrm{~cm}^{-1}\right)$ & $2.226 \times 10^{4}$ & $1.928 \times 10^{4}$ \\
\hline Sandell's sensitivity $\left(\mu \mathrm{g} \mathrm{cm}^{-2}\right)$ & 0.00670 & 0.00528 \\
\hline Limit of detection $\left(\mu \mathrm{g} \mathrm{ml}^{-1}\right)$ & 0.358 & 0.704 \\
\hline Limit of quantification $\left(\mu \mathrm{g} \mathrm{ml}^{-1}\right)$ & 2.893 & 3.362 \\
\hline Regression $^{\mathrm{a}}$ ) slope $a$ & 0.1612 & 0.1910 \\
\hline Intercept $b$ & 0.0521 & 0.0142 \\
\hline Correlation coefficient $r$ & 0.9987 & 0.9998 \\
\hline Relative standard deviation $(\%)^{\mathrm{b}}$ & 0.671 & 0.574 \\
\hline Range of error ( $95 \%$ confidence level) & \pm 0.730 & \pm 0.623 \\
\hline
\end{tabular}

a) Regression curve: $y=a x+b$, where ' $x$ ' is the concentration of vanadium $\left(\mu \mathrm{g} \mathrm{ml}^{-1}\right)$ and ' $y$ ' is absorbance, $^{\mathrm{b}}$ ) determination for $\mathrm{n}=5$. 


\section{Reaction mechanism}

Under the reaction condition, 2,4-DNPH losses probably $2 \mathrm{e}^{-}$and a proton on oxidation with $\mathrm{V}^{5+}$ in basic medium to form an electrophilic intermediate (active coupling species), which couples with NEDA to give a red derivative and the reaction mechanism was shown in Scheme 1.

Similarly, 4-amino pyridine is oxidized first with $\mathrm{V}^{5+}$, which mildly oxidizing in acidic medium. to form an electrophilic intermediate (active coupling species), which couples with NEDA giving a pink color product and the reaction mechanism was shown in Scheme 2.

\section{The effect of non-target species}

The effect of various species on the determination of vanadium was investigated. The tolerance limit was taken as the amount that caused $\pm 2 \%$ absorbance error in determination of $2.5 \mu \mathrm{g} \mathrm{ml}^{-1}$ (2,4- DNPH-NEDA method) and $3.0 \mu \mathrm{g} \mathrm{ml}^{-1}$ (4-amino pyridine- NEDA method) of $\mathrm{V}(\mathrm{V})$ and the results were shown in Table 2.

The developed method is based on the oxidation of 2,4- DNPH-NEDA and 4-amino pyridine- NEDA with vanadium. Therefore, strong oxidizing or reducing species are expected to interfere by oxidation of 2,4- DNPH-NEDA and 4-amino pyridine- NEDA on the reduction of V (V). Chromium (VI), iron (III), cerium (IV) and tungsten (VI) at a $10 \mu \mathrm{g}$ level caused low recovery of vanadium. Iron (II), copper (II), iodate, molybdenum (VI), and thiosulphate up to $350 \mu \mathrm{g}$ level caused positive interferences. Masking agents like citrate, tartrate, EDTA and sodium fluoride are not interfering in the recovery of vanadium.

Table 2. Effect of non-target species in the determination of vanadium (V) $2.5 \mu \mathrm{g} \mathrm{ml}^{-1}$ for 2,4- DNPH-NEDA and $3.0 \mu \mathrm{g} \mathrm{ml}^{-1}$ for 4-AP-NEDA method.

\begin{tabular}{|c|c|c|}
\hline Non-target species & $\begin{array}{l}\text { Tolerance Limit } \\
\left(\mu \mathrm{g} \mathrm{mL}^{-1}\right)\end{array}$ & Effect \\
\hline \multicolumn{3}{|l|}{ 2,4-DNPH-NEDA method } \\
\hline $\begin{array}{l}\mathrm{Na}^{+}, \mathrm{Mg}^{2+}, \mathrm{Cl}^{-}, \mathrm{NO}_{3}^{-}, \mathrm{F}^{-}, \mathrm{CHCOO}^{-}, \mathrm{CO}_{3}{ }^{2-}, \\
\mathrm{K}^{+}, \mathrm{Hg}^{2+}, \mathrm{Ca}^{2+}, \mathrm{BO}_{3}^{-}, \mathrm{NO}_{3}^{-}, \mathrm{SO}_{4}{ }^{2-}, \mathrm{PO}_{4}{ }^{3-}, \\
\text { citrate, oxalate, tartarate }\end{array}$ & 3600 & No interference \\
\hline $\mathrm{P}_{2} \mathrm{O}_{7}^{4-}, \mathrm{SeO}_{3}^{2-}, \mathrm{SbO}_{7}^{2-}$ & 2500 & No interference \\
\hline $\mathrm{Al}^{3+}, \mathrm{Cd}^{2+}, \mathrm{Ba}^{2+}, \mathrm{Ni}^{2+}, \mathrm{Co}^{2+}, \mathrm{Te}^{4+}, \mathrm{Zn}^{2+}$ & 600 & No interference \\
\hline $\mathrm{Cu}^{2+}, \mathrm{Ce}^{4+}, \mathrm{Fe}^{3+}, \mathrm{Cr}^{3+}, \mathrm{Sn}^{2+}, \mathrm{Pb}^{2+}, \mathrm{W}^{6+}, \mathrm{Mo}^{6+}$ & $64^{\mathrm{a}}$ & Positive interfere \\
\hline $\begin{array}{l}\text { 4-AP-NEDA method } \\
\mathrm{K}^{+}, \mathrm{Hg}^{2+}, \mathrm{Ca}^{2+}, \mathrm{BO}_{3}^{-}, \mathrm{NO}_{3}^{-}, \mathrm{SO}_{4}{ }^{2-}, \mathrm{PO}_{4}^{3-}, \\
\mathrm{Na}^{+}, \mathrm{Mg}^{2+}, \text { Tartarate, citrate, oxalate, } \\
\text { tartarate, Oxalate, } \mathrm{Mn}^{2+}, \mathrm{NO}^{2-}\end{array}$ & 3800 & No interference \\
\hline $\mathrm{Ba}^{2+}, \mathrm{SO}_{4}{ }^{2-}, \mathrm{CN}^{-}, \mathrm{SCN}^{-}, \mathrm{SeO}_{3}{ }^{2-}, \mathrm{SbO}_{7}{ }^{2-}$ & 1500 & No interference \\
\hline $\mathrm{P}_{2} \mathrm{O}_{7}^{4-}, \mathrm{SeO}_{3}{ }^{2-}, \mathrm{SbO}_{7}{ }^{2-}, \mathrm{SO}_{3}{ }^{2-}$ & 800 & No interference \\
\hline $\mathrm{Al}^{3+}, \mathrm{Cd}^{2+}, \mathrm{Ba}^{2+}, \mathrm{Ni}^{2+}, \mathrm{Co}^{2+}, \mathrm{As}^{5+}, \mathrm{Te}^{4+}, \mathrm{Zn}^{2+}$ & 300 & No interference \\
\hline $\mathrm{Cu}^{2+}, \mathrm{Ce}^{4+}, \mathrm{Fe}^{3+}, \mathrm{Cr}^{3+}, \mathrm{Sn}^{2+}, \mathrm{Pb}^{2+}, \mathrm{W}^{6+}, \mathrm{Mo}^{6+}$ & $84^{\mathrm{b}}$ & $\begin{array}{l}\text { Positive } \\
\text { interference }\end{array}$ \\
\hline
\end{tabular}

${ }^{\mathrm{a}}$ Can be masked up to $64 \mu \mathrm{g} \mathrm{mL} \mathrm{m}^{-1}$ by the addition of $2 \mathrm{~mL}$ of $2 \%$ EDTA.

${ }^{\mathrm{a}} \mathrm{Can}$ be masked up to $84 \mu \mathrm{g} \mathrm{mL} \mathrm{m}^{-1}$ by the addition of $5 \mathrm{~mL}$ of $2 \%$ EDTA. 
<smiles>Nc1ccc([N+](=O)[O-])cc1[N+](=O)[O-]</smiles>

2,4-dinitro phenyl hydrazine

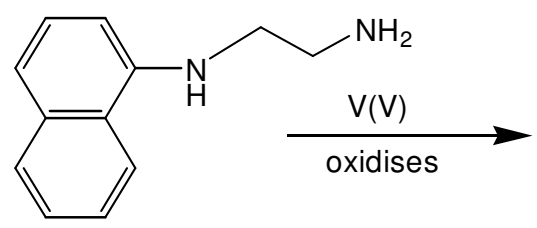

NEDA<smiles>NCCN=C1C=CC(=N[NH2+]c2ccc([N+](=O)[O-])cc2[N+](=O)[O-])c2ccccc21</smiles>

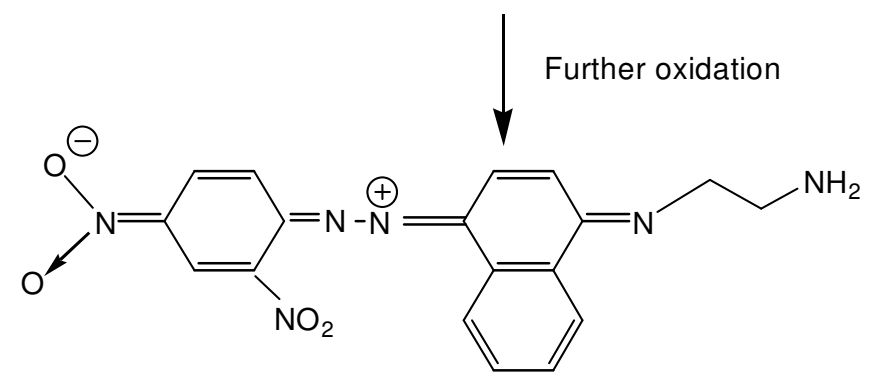<smiles></smiles>

Red colored derivative

Scheme 1: Oxidative coupling reaction of 2,4-dinitrophenylhydrazine witr NEDA by Vanadium(V)

Therefore, these masking agents were used to obviate interferents such as iron (III), cerium (IV) and tungsten (VI) up to a $10 \mu \mathrm{g}$ level in the determination of vanadium. Small concentrations of As (III) at temperature $\geq 45^{\circ} \mathrm{C}$ can effectively reduce chromium (VI) and quantitatively eliminate its effects on the coloring reagent. Therefore, As (III) ion was 
adopted as an effective reducing agent for $\mathrm{Cr}(\mathrm{VI})$ in the presence of vanadium $(\mathrm{V})^{14}$. If a precipitate was formed during the interference studies, it was removed by centrifugation.

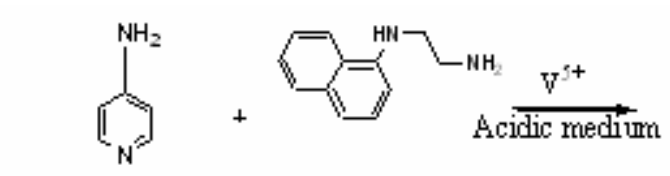

4Aminopyidine

NEDA
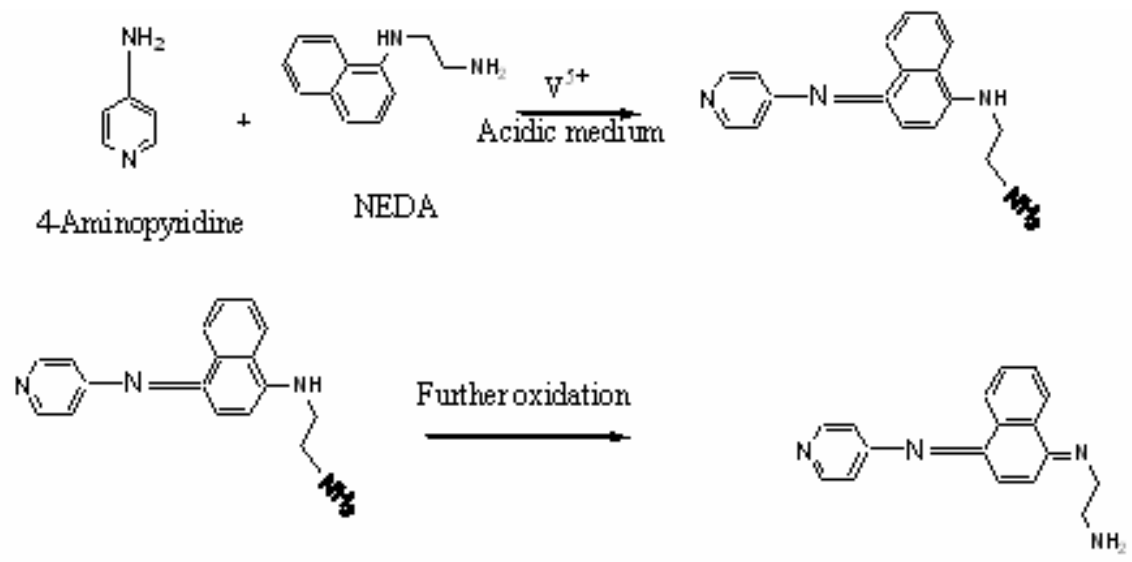

Pink colored de rivative

Scheme 2 Oxidative coupling reaction of 4 aminopyidine-HEDA with $\mathrm{V}(\mathrm{V})$

\section{Applications of proposed methods}

The rapidity of color development with 2,4- DNPH-NEDA and 4-amino pyridine- NEDA is an advantage in analyzing various samples, in which vanadium can vary over a wide range. When compared to other existing methods, the developed method retains the specific interaction of vanadium (V) with 2,4- DNPH-NEDA and 4-amino pyridine- NEDA to form colored derivatives and a good sensitivity is achieved at room temperature without the need for extraction. Hence, the use of organic solvents, which are generally toxic or carcinogens are avoided. The proposed method has significant advantages over other spectrophotometric methods $9,10,18,19$ in terms of its simplicity and free from most interfering substances. Accurate and reproducible results are obtained with permissible standard deviations.It is evident from the above data that the proposed method is simple, highly sensitive and rapid than the reported method in literature as shown in Table 4.

\section{Application of proposed method and statistical comparison with reported method}

The proposed methods are applied to the determination of vanadium $(\mathrm{V})$ in pharmaceutical preparations, steels, and environmental and biological samples. The results were compared with the reported methods ${ }^{8,16}$ and results were summarized in Table 3. The performances of the proposed methods were compared statistically in terms of Students ' $t$ ' test and the Variance ratio ' $F$ ' test. At $95 \%$ confidence level, the calculated ' $t$ ' values and ' $F$ ' values do not exceed the theoretical values for the two methods. The theoretical ' $t$ ' value was 2.65 $(\mathrm{n}=5)$ and ' $F$ ' values was $5.72(\mathrm{n}=5)$. It is found that from Table 3 that there is no significant difference between the proposed methods and reported methods ${ }^{8,16}$, indicating that the proposed methods are as accurate and precise as the reported methods. 
Table 3. Determination of Vanadium (V) in various samples

\begin{tabular}{|c|c|c|c|c|c|c|c|c|c|c|c|}
\hline \multirow{3}{*}{ Sample } & \multirow{3}{*}{$\begin{array}{l}\text { Vanadium } \\
\text { added } \\
(\mathrm{ppm})\end{array}$} & \multicolumn{8}{|c|}{ Proposed methods } & \multirow{3}{*}{$\begin{array}{l}\text { Reference } \\
\text { method }^{15}\end{array}$} & \multirow{3}{*}{ ICP-OES $^{8}$} \\
\hline & & \multicolumn{3}{|c|}{ 2,4-DNPH-NEDA method } & & \multicolumn{4}{|c|}{ 4-AP-NEDA method } & & \\
\hline & & Found $^{\mathrm{a}}$ & Recovery & $\begin{array}{l}\text { t \& F } \\
\text { tests }\end{array}$ & $\begin{array}{l}\mathrm{t} \& \mathrm{~F} \\
\text { tests }\end{array}$ & Found $^{\mathrm{a}}$ & Recovery & $\begin{array}{l}\mathrm{t} \& \mathrm{~F} \\
\text { tests }\end{array}$ & $\begin{array}{l}\mathrm{t} \& \mathrm{~F} \\
\text { tests }^{\mathrm{b}}\end{array}$ & & \\
\hline \multirow[t]{4}{*}{ Soil $^{\mathrm{e}}$} & 3.0 & $2.97 \pm 0.02$ & 99.00 & $\mathrm{t}=-3.04$ & $\mathrm{t}=-7.19$ & $2.96 \pm 0.02$ & 98.66 & $\mathrm{t}=-2.97$ & $\mathrm{t}=-8.19$ & $2.95 \pm 0.03$ & $2.99 \pm 0.02$ \\
\hline & & & & $\mathrm{F}=0.28$ & $\mathrm{~F}=0.64$ & & & $\mathrm{~F}=0.70$ & $\mathrm{~F}=0.80$ & & \\
\hline & 9.0 & $8.96 \pm 0.02$ & 99.55 & $\mathrm{t}=-4.83$ & $\mathrm{t}=-5.93$ & $8.95 \pm 0.02$ & 99.44 & $\mathrm{t}=-1.91$ & $\mathrm{t}=-7.39$ & $8.94 \pm 0.02$ & $9.98 \pm 0.01$ \\
\hline & & & & $\mathrm{F}=0.80$ & $\mathrm{~F}=0.48$ & & & $\mathrm{~F}=0.87$ & $\mathrm{~F}=0.76$ & & \\
\hline \multirow{4}{*}{$\begin{array}{l}\text { Natural } \\
\text { water }^{\mathrm{e}}\end{array}$} & 4.0 & $3.98 \pm 0.01$ & 99.50 & $\mathrm{t}=-2.39$ & $\mathrm{t}=-3.42$ & $3.97 \pm 0.01$ & 99.25 & $\mathrm{t}=-8.01$ & $t=-3.66$ & $3.96 \pm 0.01$ & $5.99 \pm 0.02$ \\
\hline & & & & $\mathrm{F}=0.26$ & $\mathrm{~F}=0.22$ & & & $\mathrm{~F}=0.37$ & $\mathrm{~F}=0.14$ & & \\
\hline & 9.0 & $8.97 \pm 0.01$ & 99.66 & $\mathrm{t}=4.89$ & $\mathrm{t}=-4.46$ & $8.96 \pm 0.01$ & 99.55 & $\mathrm{t}=-7.82$ & $\mathrm{t}=-4.04$ & $8.95 \pm 0.01$ & $10.0 \pm 0.01$ \\
\hline & & & & $F=0.56$ & $\mathrm{~F}=0.30$ & & & $\mathrm{~F}=1.0$ & $\mathrm{~F}=0.11$ & & \\
\hline \multirow[t]{4}{*}{ Urine $^{\mathrm{e}}$} & 5.0 & $4.98 \pm 0.01$ & 99.60 & $\mathrm{t}=1.47$ & - & $4.96 \pm 0.01$ & 99.20 & $\mathrm{t}=-4.78$ & - & $4.94 \pm 0.02$ & - \\
\hline & & & & $\mathrm{F}=1.0$ & & & & $\mathrm{~F}=1.0$ & & & \\
\hline & 9.0 & $8.98 \pm 0.01$ & 99.77 & $\mathrm{t}=2.89$ & - & $8.97 \pm 0.01$ & 99.66 & $t=-7.56$ & - & $8.96 \pm 0.01$ & - \\
\hline & & & & $\mathrm{F}=0.63$ & & & & $\mathrm{~F}=1.0$ & & & \\
\hline \multirow{6}{*}{$\begin{array}{l}\text { Human } \\
\text { hair } \\
\text { Goat } \\
\text { liver }\end{array}$} & - & $1.99 \pm 0.01$ & - & $t=1.64$ & - & $1.98 \pm 0.01$ & - & $\mathrm{t}=1.22$ & - & $1.97 \pm 0.02$ & - \\
\hline & & & & $\mathrm{F}=0.41$ & & & & $\mathrm{~F}=0.41$ & & & \\
\hline & 7.0 & $6.98 \pm 0.01$ & 99.71 & $t=5.78$ & - & $6.96 \pm 0.01$ & 99.42 & $\mathrm{t}=4.89$ & - & $6.95 \pm 0.01$ & - \\
\hline & & & & $\mathrm{F}=0.61$ & & & & $\mathrm{~F}=0.41$ & & & \\
\hline & 10.0 & $9.99 \pm 0.01$ & 99.90 & $\mathrm{t}=-1.25$ & - & $9.98 \pm 0.01$ & 99.80 & $t=-1.16$ & - & $9.97 \pm 0.01$ & - \\
\hline & & & & $\mathrm{F}=0.32$ & & & & $\mathrm{~F}=0.14$ & & & \\
\hline \multirow{4}{*}{$\begin{array}{l}\text { Plant } \\
\text { material }\end{array}$} & 9.0 & $8.98 \pm 0.01$ & 99.77 & $\mathrm{t}=-2.39$ & - & $8.97 \pm 0.01$ & 99.66 & $\mathrm{t}=-2.39$ & - & $8.96 \pm 0.02$ & - \\
\hline & & & & $\mathrm{F}=0.18$ & & & & $\mathrm{~F}=0.18$ & & & \\
\hline & 12.0 & $11.98 \pm 0.01$ & 99.83 & $\mathrm{t}=-1.17$ & - & $11.96 \pm 0.01$ & 99.66 & $\mathrm{t}=-1.42$ & - & $11.97 \pm 0.02$ & - \\
\hline & & & & $\mathrm{F}=0.65$ & & & & $\mathrm{~F}=0.9$ & & & \\
\hline \multirow[t]{2}{*}{ Steel $^{\mathrm{d}}$} & - & $3.98 \pm 0.01$ & - & $\mathrm{t}=-2.39$ & - & $3.97 \pm 0.01$ & & $\mathrm{t}=-1.02$ & - & $3.96 \pm 0.01$ & - \\
\hline & & & & $\mathrm{F}=0.26$ & & & & $\mathrm{~F}=0.37$ & & & \\
\hline
\end{tabular}




\begin{tabular}{|c|c|c|c|c|c|c|c|}
\hline \multirow[t]{2}{*}{$\begin{array}{l}\text { Pharmaceutical } \\
\text { preparation }^{c}\end{array}$} & $7.90 \pm 0.01$ & 98.75 & $\begin{array}{l}t=1.95 \\
F=0.83\end{array}$ & $7.89 \pm 0.01$ & 98.62 & $\begin{array}{l}\mathrm{t}=-3.90 \\
\mathrm{~F}=0.45\end{array}$ & $7.86 \pm 0.01$ \\
\hline & $13.90 \pm 0.02$ & 99.28 & $\begin{array}{l}\mathrm{t}=3.68 \\
\mathrm{~F}=0.39\end{array}$ & $13.89 \pm 0.02$ & 99.21 & $\begin{array}{l}\mathrm{t}=4.79 \\
\mathrm{~F}=0.50\end{array}$ & $13.87 \pm 0.03$ \\
\hline
\end{tabular}

${ }^{\mathrm{a}}$ Mean \pm standard deviation $(\mathrm{n}=5)$. ${ }^{\mathrm{b}}$ Tabulated $t$-value for 8 degrees of freedom at $P(0.95)$ is 2.65 and tabulated F-value for $(4,4)$ degrees of freedom at $P(0.95)$ is 5.72. ${ }^{\mathrm{c}}$ Neogadine Elixir®, Raptakos Brett \& Co. Ltd. India [Each $15 \mathrm{ml}$ contains Iodised peptone 29 mg, magnesium chloride $20 \mathrm{mg}$, magnesium sulfate $4 \mathrm{mg}$, sodium metavanadate $0.66 \mathrm{mg}$, zinc sulfate $6 \mathrm{mg}$, pyridomine $\mathrm{HCl} 0.75 \mathrm{mg}$, cyanocobalamin $0.5 \mu \mathrm{g}$, nicotinamide $10 \mathrm{mg}$, alcohol $(95 \%) 0.95 \mathrm{ml}$, Total alcohol 6\% (v/v)], vanadium taken 7.89 ppm. ${ }^{\mathrm{d}}$ GKW Steel Ltd., India [C, 0.54\%; Mn, 0.89\%; S, 0.018\%; P, 0.034\%; Si, 0.33\%; Cr, 1.02\%; V, 0.13\%], vanadium taken 3.9 ppm. ${ }^{\mathrm{e}} \mathrm{Gave}$ no test for vanadium.

Table 4. Comparison of spectrophotometric and catalytic photometric methods for the determination of vanadium (V) with 2,4-DNPH-NEDA and 4-AP-NEDA methods

\begin{tabular}{|c|c|c|c|}
\hline Reagent & $\begin{array}{c}\text { Range of } \\
\text { determination } \\
\left(\mu \mathrm{g} \mathrm{ml}^{-1)}\right.\end{array}$ & Remarks & Reference \\
\hline Pyrogallol & $0.01-0.6$ & Less sensitive & [13] \\
\hline 2-hydroxyacetophenone oxime & $0.05-4.0$ & Less sensitive and less detection limit & [15] \\
\hline 2-(5-chloro-2-pyridylazo) -5-dimethylamino phenol & $0.02-5.0$ & $\begin{array}{l}30 \mathrm{~min} \text { is needed for color development and } \\
\text { require solvents for the extraction of color } \\
\text { derivatives }\end{array}$ & [16] \\
\hline Varamine blue & $0.1-2.0$ & Less sensitive and less stable & {$[10]$} \\
\hline N,N'-bis)2-hydroxyl-3-sulfopropyl)-tolidine & $0.01-3.0$ & Require tiron activator & [19] \\
\hline 2-benzoylacetate & $0.05-4.0$ & $\begin{array}{l}\text { Poor selectivity and interfering large } \\
\text { number of metal ions }\end{array}$ & [12] \\
\hline Eriochrom cyanine $\mathrm{R}$ & $0.01-5.0$ & $\begin{array}{l}\text { Require solvents for the extraction, large } \\
\text { number of metal ions are interfere }\end{array}$ & {$[11]$} \\
\hline 2,4-DNP-NEDA & $0.02-3.5$ & Facile, Sensitive, rapid, non-extractive, & Present \\
\hline 4-AP-NEDA & $0.03-4.5$ & stable color derivatives and less nterference & work \\
\hline
\end{tabular}




\section{Conclusions}

The coupling reagents employed in the present methods, i.e., 2,4- DNPH-NEDA and 4amino pyridine- NEDA are sensitive and selective spectrophotometric reagents for the determination of vanadium $(\mathrm{V})$. In these methods, non-target species do not interfere with the determination of vanadium $(\mathrm{V})$ when masked with EDTA, citrate, tartarate and sodium fluoride. The detection limit $0.358 \mu \mathrm{g} \mathrm{ml}^{-1}$ for 2,4- DNPH-NEDA and $0.704 \mu \mathrm{g} \mathrm{ml}^{-1}$ for 4amino pyridine- NEDA in original samples and $\mu \mathrm{g}^{-1}$ level of vanadium in water and biological samples can be determined with good results. In these methods, avoid organic solvents for the extraction of color derivatives; it indicates the present methods are non-toxic and safer than those methods using other organic solvents. Statistical analysis of the results indicates that the methods yield exact values.

Hence, the proposed methods successfully applied for the determination of vanadium (V) in environmental, biological, and steel samples.

\section{References}

1. Eric Underwood J, Trace Elements in Human and Animal Nutrition (Academic Press USA), 1978.

2. De Beer H and Coetzee P P, Fresenius' J. Anal. Chem, 1994 , 348, 806.

3. Ensafia A and Naderi B, Fresenius' J. Anal. Chem, 1997, 358, 480.

4. Chakraborty R and Das K, Fresenius' J. Anal. Chem, 1994,349, 774.

5. Yaman M and Gucer S, Fresenius' J. Anal. Chem, 1994, 350, 504.

6. Kawakubo S, Ogihara K and Iwatsuki M, Analyst, 1995,2719.

7. Dopant V, Auger Y and Jeandel C, Water, M. Anal. Chem, 1991, 63, 520.

8. Coetzee P P, Fischer J L and Mingsong H, Water SA ,2002,28, 37.

9. Qiufen $\mathrm{Hu}$, Yang G and Yin J, Bull. Korean Chem. Soc,2004, 25, 263.

10. Kiran Kumar T N and Revanasiddappa H D , Iranian J. Chem. Soc, 2005, 2, 161.

11. Bosque-Sendra J M, Valencia L C and Boudra S, Fresenius' J. Anal. Chem, 1998, $360,31$.

12. Chauhan R S and Kakkar L R, Bull. Chem. Soc. Japan, 1992, 65, 1033.

13. Iranpoor N, Maleki N, Razi S and Safavi A, Talanta, 1992, 39,281.

14. Miura J H, Anal. Chim, 1990, 62,1424.

15. Murthy G V R, Reddy T S and Rao S B, Analyst, 1989, 114, 493.

16. Taylor M J C, Marshall G D, Williams S J S, Vanstaden J F and Sailing C, Anal. Chim. Acta, 1996, 329,275.

17. Serrat F B and Morell G B, Fresenius' J. Anal. Chim, 1994, 349, 717.

18. Zucchi C, Forneris M, Martizez L, Oisina R and Marchevsky E, Fresenius' J. Anal. Chem, 1998, 360, 128.

19. Shigenori N, Tanaka E and Mizutani Y, Talanta, 2003, 61,203.

20. Glick D,Methods of Biochemical Analysis, John wiley 1973.

21. Amed M J and Banoo S, Talanta, 1999, 48(5),1085. 


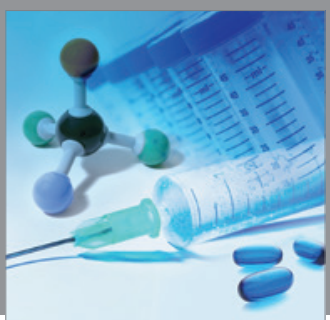

International Journal of

Medicinal Chemistry

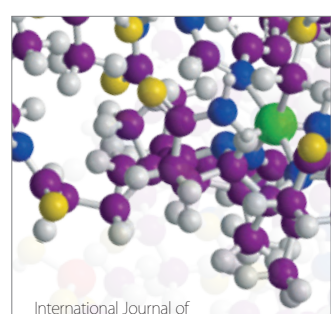

Carbohydrate Chemistry

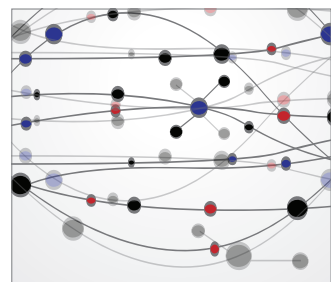

The Scientific World Journal
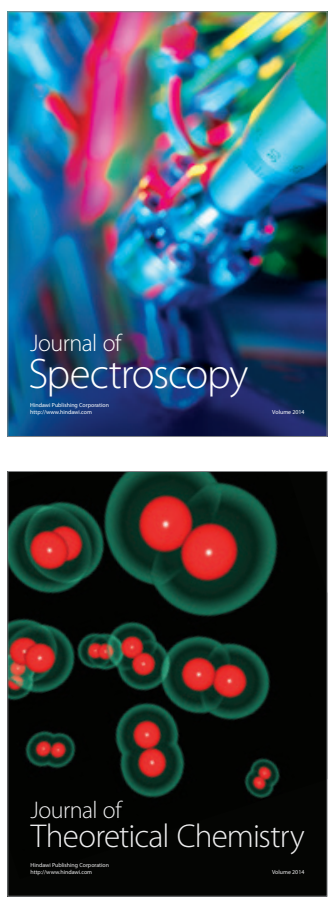
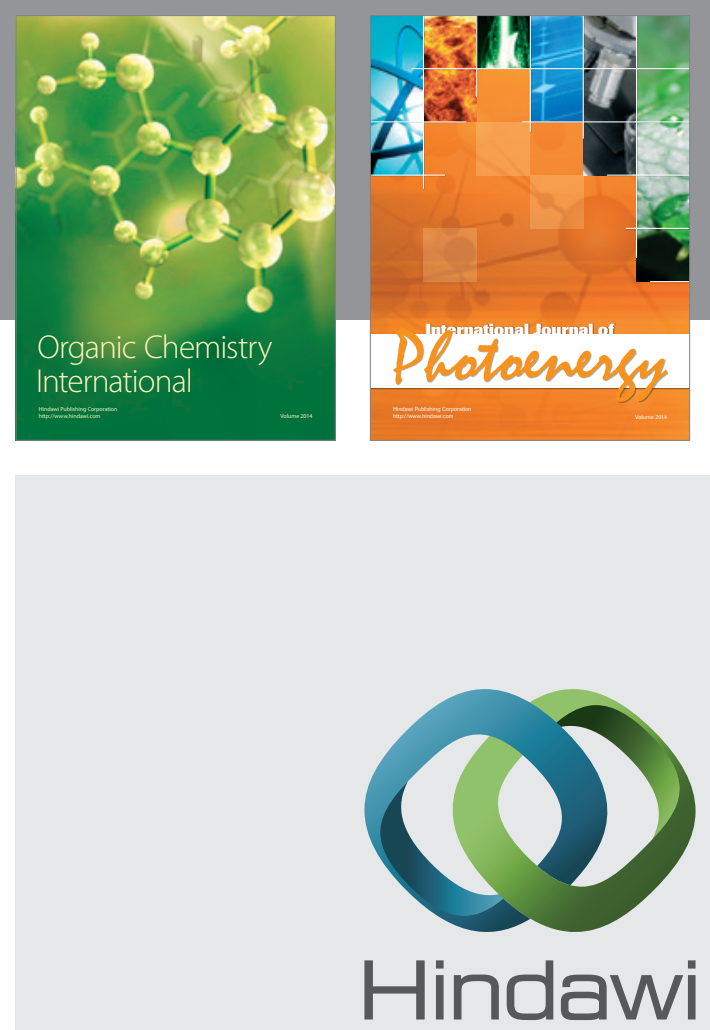

Submit your manuscripts at

http://www.hindawi.com
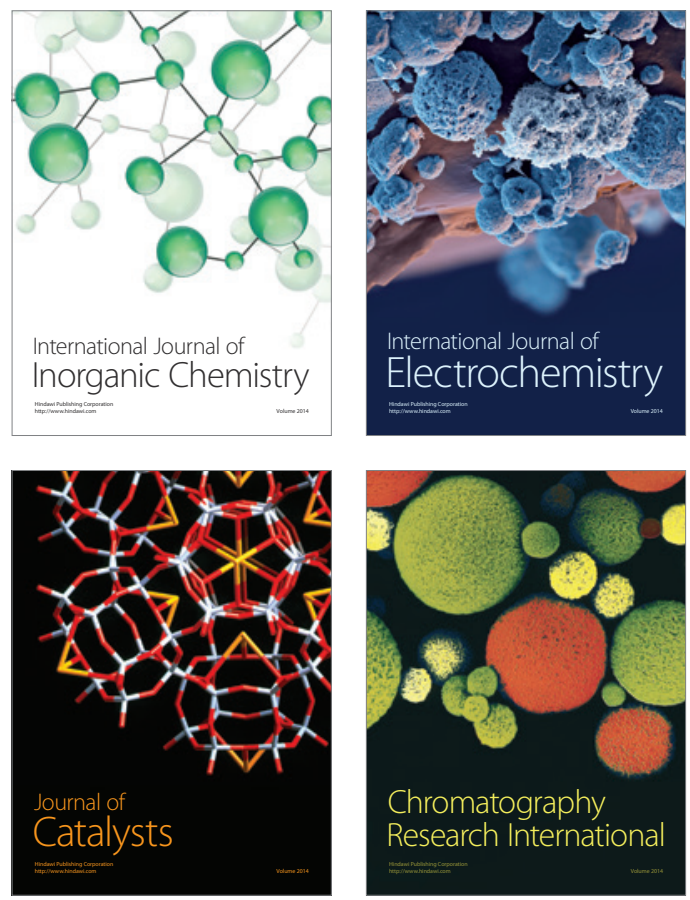
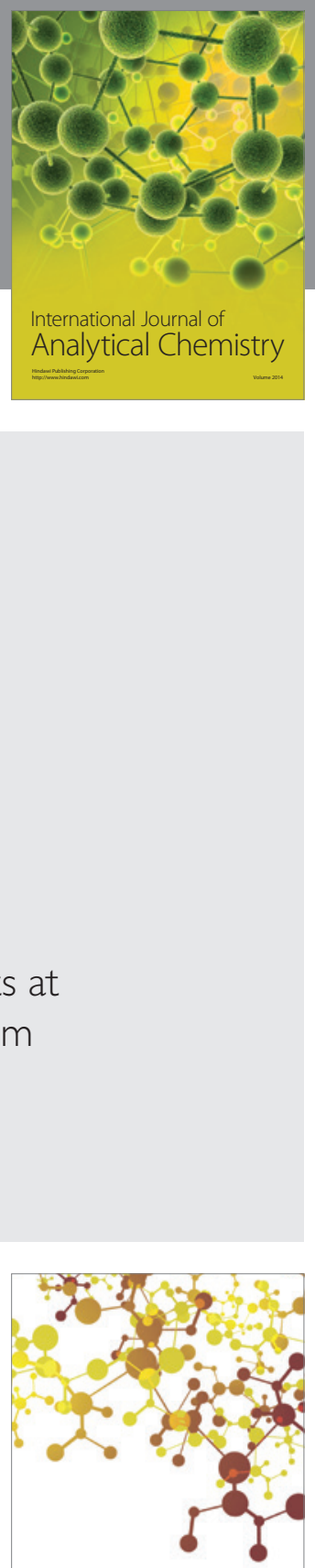

Journal of

Applied Chemistry
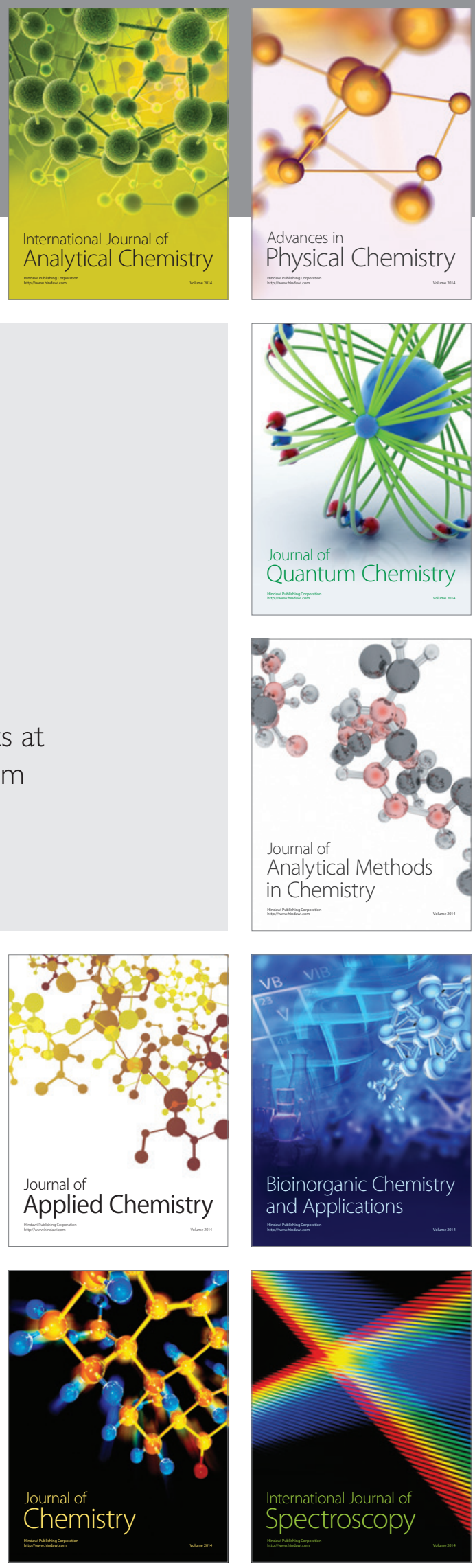